Check for updates

The BMJ

fgodlee@bmi.com Follow Fiona on Twitter @fgodlee

Cite this as: BMJ2020;371:m4077 http://dx.doi.org/10.1136/bmi.m4077 Published: 22 October 2020

\section{Why this US election matters so much}

\section{Fiona Godlee editor in chief}

With only days to go before the US presidential election, ${ }^{1}$ the editors of medical and science journals have entered the political fray with unprecedented unity, voicing their shared concerns about Donald Trump's record in office and his candidacy for re-election. ${ }^{2}$ Among them are two US based heavyweights that have traditionally been reticent on party political matters: Science and the New England Journal of Medicine. ${ }^{34}$ Together they have collated a devastating list of the ways in which Trump has undermined science and damaged health.

We at The BMJ welcome this criticism. Our own deep concerns about the damaging effects of Trump's presidency on science and health have been stated early and often. An editorial published soon after he took office described how his policies were already damaging trust in health science and policy. ${ }^{5}$ In the three years since then, other editorials have decried Trump's reneging on global treaties (including on climate change ${ }^{6}$ ), his decision to defund WHO, ${ }^{7}$ his attacks on reproductive rights in the US and worldwide, ${ }^{89}$ his reversals on gun control, ${ }^{10}$ and his attempts to reverse the Affordable Care Act, leaving millions of Americans without health insurance. ${ }^{11} 12$

This year Trump's incompetence has culminated in what Drew Altman calls the US's "lamentable performance" on covid-19, caused by a failure of policy and leadership. ${ }^{13}$ As the US clocks up more than eight million cases and more than 225000 deaths, Trump has become a "political determinant" of the pandemic, say Gavin Yamey and Gregg Gonsalvez. ${ }^{14}$ Trump downplayed the risks of the virus, delayed action, promoted unproved treatments, and undermined public health interventions. His actions and inaction have caused thousands of avoidable deaths. He has shown that he sees science as an opponent to be attacked, manipulated, and ridiculed..$^{15}$ One of the worst things he has found to say about his rival in recent days was that Joe Biden would "listen to the scientists" if elected. ${ }^{16}$

His other great opponent, Anthony Fauci, ${ }^{17}$ on receiving one of US science's greatest accolades this week, ${ }^{18}$ talked of the times we are going through as "disturbingly antiscience." Trump's term in office has been marked by the suppression, distortion, denigration, and denial of science. His is already a grim legacy. If he is returned to office, all of us committed to advancing science and rational debate must raise our voices loud and clear in the fight against distrust and division. ${ }^{19}$ The world will need all the cool heads, open minds, and wise counsel we can offer.

Rovner J. US election 2020: how the candidates will determine the shape of American healthcare. BMJ 2020;371:m3947. doi: 10.1136/bmj.m3947 pmid: 33051181

2 Tanne JH. Covid 19: NEJM and former CDC director launch stinging attacks on US response. BMJ 2020;371:m3925. doi: 10.1136/bmi.m3925 pmid: 33033056
3 Editors. Dying in a leadership vacuum. N Engl / Med 2020;383:1479-80. doi: 10.1056/NEJMe2029812 pmid: 33027574

4 Thorp HH. Not throwing away our shot. Science 2020;370:266.pmid: 33060334

5 Merino JG, Jha A, Loder E, Abbasi K. Standing up for science in the era of Trump. BM/2017;356:j75. doi: 10.1136/bmj.j775 pmid: 28246103

6 Haines A, Scheelbeek P, Abbasi K. The health case for urgent action on climate change. BMJ 2020;368:m1103. doi: 10.1136/bmj.m1103 pmid: 32229547

7 Sridhar D, King L. US decision to pull out of World Health Organization BMJ 2020;370:m2943. doi: 10.1136/bmj.m2943 pmid: 32709622

8 Aiken ARA. Erosion of women's reproductive rights in the United States. BMJ 2019;366:14444. doi: 10.1136/bmj.14444 pmid: 31278084

9 Hawkes S, Buse K. Trumped again: reinstating the global gag rule. BMJ 2017;356:;654. doi: 10.1136/bmi.j654 pmid: 28174159

10 Winker M, Rowhani-Rahbar A, Rivara FP. US gun violence and deaths. BMJ 2020;368:m1074. doi: 10.1136/bmj.m1074 pmid: 32205314

11 Gaffney A. Illness should not inflict financial ruin. BMJ 2020;368:m327. doi: 10.1136/bmi.m327 pmid: 32024652

12 Steinbrook R. Healthcare in Trump's first year. BMJ 2018;360:k173. doi: 10.1136/bmj.k173 pmid: 29339366

13 Altman D. Understanding the US failure on coronavirus-an essay by Drew Altman. BM/2020;370:m3417. doi: 10.1136/bmj.m3417 pmid: 32928876

14 Yamey G, Gonsalves G. Donald Trump: a political determinant of covid-19. BMJ 2020;369:m1643. doi: 10.1136/bmj.m1643 pmid: 32332028

15 Gonsalves G, Yamey G. Political interference in public health science during covid-19. BM/2020;371:m3878. doi: 10.1136/bmj.m3878 pmid: 33023874

16 Biden will listen to the scientists. YouTube. 18 Oct 2020 https://www.youtube.com/watch?v=It|x8CLS3tw.

17 Godlee F, Silberner J. The BMJ interview: Anthony Fauci on covid-19. BMJ 2020;370:m3703. doi: 10.1136/bmj.m3703 pmid: 32967907

18 Hopkins TJ. Covid-19: Fauci awarded for "unprecedented public service" while Trump fires more insults. BM/2020;371:m4064.

19 Davey Smith G, Blastland M, Munafò M. Covid-19's known unknowns. BMJ 2020;371:m3979. 